\title{
Firm culture and management accounting practices among manufacturing firms in Nigeria
}

\author{
Oluyinka Isaiah Ogungbade ${ }^{1 *}$ (1) and Ezekiel Oluwagbemiga Oyerogba ${ }^{2}$
}

\begin{abstract}
This study sought to find out the effects of firm culture on management accounting practices (MAPs). The study used a structured questionnaire to collect data from 220 randomly selected manufacturing firms out of 514 firms and used logistic regression for analysis. This study examined seven dimensions of firm cultures, including innovation/ risk orientation culture, people orientation culture, outcome orientation culture, aggressive culture, stability culture, team-based culture, and attention to details culture. The study established that team-based, attention to details, and stability cultures have a significant influence on the choice of management accounting practices. In contrast, the considerable influence of other cultural dimensions lacks statistical support. The study concludes that attention to details culture and team-based culture are barriers to modern management accounting practices, and cautions should be exercised by managers in using these cultures. Therefore, this study recommends that manufacturing firms in Nigeria should be cautious of their culture and its implication on MAPs. In a more specific term, they should practice cultures that will allow them to choose modern MAPs and take advantage of the benefits attached.
\end{abstract}

Keywords: Firm culture, Management accounting practices, Manufacturing

\section{Introduction}

The relevance loss of management accounting information in the twenty-first-century business environment due to advanced manufacturing technology and intense competition [30] has led to the development of sophisticated management accounting techniques $[9,10]$. The arrival of new technologies has undoubtedly caused alterations in the structure and practice of management accounting techniques [8]. The modifications may cause firms to review their existing practices to become relevant in the dynamic environment [36]. The focus of management accounting on the provision of accounting information for management planning and control in the second phase of its development, the second 50 years (1969-2019), had caused very rapid changes in how management accountants think and work. It is unlike in the first phase of its development, the first

\footnotetext{
*Correspondence: ogungbadeoi@abuad.edu.ng

${ }^{1}$ Afe Babalola University Ado-Ekiti, Km 8.5, Afe Babalola Way, P.M.B. 5454,

Ado-Ekiti, Ekiti State, Nigeria

Full list of author information is available at the end of the article
}

50 years(1919-1969), when the emphasis was on cost determinations [24]. These changes have also led to new management accounting techniques such as activitybased costing and balanced scorecard. The new methods are believed to be more sophisticated than traditional management accounting techniques such as standard costing and absorption costing, which dominated the practice in the first phase but considered obsolete and unhelpful in the second and subsequent phases.

However, despite the many inadequacies attributed to the traditional management accounting techniques and several benefits associated with modern management accounting techniques, which were developed to address the shortcomings of conventional MAPs, manufacturing companies in Nigeria are predominantly practicing traditional MAPs except few that practice current MAPs [48]. The reason for this is worrisome because the next phase of management accounting development has already started since 2019. The expectation from management accountants is to become experts in using the latest digital technology such as blockchain, AI, augmented reality, and data analytics, among others, to make decisions that 
improve businesses and society [24]. An investigation of the reason for the slow pace of adoption of new MAPs revealed that firm culture is a significant constraint $[3,14$, 51]. Firm culture is the entirety of values, symbols, meanings, norms, and expectations capable of unifying a group of people working together [12]. Velasquez et al. [58] suggested research into the relationship between management accounting and firm culture because they opine that cost accounting is a crucial component of management accounting, and cost consciousness is associated with organizational cultures and values. Likewise, Ghasemi et al. [25] called for further research on the influence of culture on management accounting practices. The call was premised on the fact that the adoption and practice of new management accounting techniques that were developed in advanced countries may not be effective in developing countries because of different national and organizational cultures.

Firm culture has been suggested to influence the choice of management accounting practices, but this relationship has not enjoyed the attention of authors in Nigeria. Ominunu [46] posits that firms' cultures in Nigeria do not welcome the adoption and use of new managerial accounting practices. However, Ominunu [46] did not examine any particular cultural dimension, and neither were the study's respondents the representative of any company; therefore, findings of the study should be taken with caution.

The influence of culture on the choice of management accounting practices and optimal performance of the firms cannot be overemphasized. The liquidation of some companies, such as Enron and WorldCom, was associated with their cultures [47]. Furthermore, the extant literature reveals that many manufacturing jobs were lost in the 1990s as a result of liquidation and relocation [4]. Their abysmal performance is not unconnected with their uninformed decisions occasioned by reliance on traditional management accounting information [45].

The failure of traditional management accounting practices to provide reliable information for management to make an informed decision was due to changes in internal and external business environments, including market competition, manufacturing technology, firms' strategy, and culture. The factors mentioned above have rendered traditional management accounting information irrelevant and unreliable in twenty-first-century business environments $[9,10]$. The extant literature shows that firm culture affects the quality of management accounting information system [40].

Even though studies on the association of firms culture and MAPs have produced mixed results [14, 51], lack of empirical evidence in Nigeria and the consequence of the wrong alignment of firms culture and MAPs have also made this investigation very imperative.

\section{Theoretical and empirical review}

This section comprises theoretical and empirical reviews of relevant literature.

\section{Theoretical Review}

This study principally employs contingency theory and supports it with old institutional theory.

\section{Contingency theory}

Some studies have proposed the neo contingency theory, which implies integrating different approaches $[19,20]$. These studies of Donaldson represent the evolution of contingency theory [38]. The contingency theory, also known as the situational approach theory of organization, is very significant in management accounting research; hence, it has been tremendously used by researchers in the field [1]. Contingency theory has been described as a significant development to the behavioral Management accounting research, which seeks to define specific aspects of an accounting system design that is appropriate for different sets of circumstances [1]. The theory which takes its root from organization contingency theory is an approach to the study of organizational behavior in which explanations are given as to how contingent factors such as technology, culture, and the external environment influence the design and function of organizations. Thus, the theory has generated considerable interest among management accounting researchers. This study hypothesizes that the management accounting practices among manufacturing firms in Nigeria are contingent upon the culture of each firm.

Several studies conducted in developing countries used contingency theory aimed at assessing the contingency causalities established in developed countries or to identify new contingency factors in a given social setting [2]. The contingency approach is used in surveybased research [1,21, 27, 48] and in case studies [59] in less developed counties. However, being a theory that is mainly based on rationalism, contingency theory has been criticized for not being very powerful in explaining the factors affecting management accounting practices in less developed counties $[9,10]$. Other subsequent studies have supported the argument of Bhimani and Bromwich $[9,10]$. Hopper et al. [28] suggest that in developing countries, coercion tools or the need for legitimacy is more critical than rational control.

Similarly, Gong and Tse [26] argue that the contingency approach needs to be supplemented with other sociological theories because of its limited ability to provide a deeper understanding of the reasons underlying 
the adoption of management accounting techniques or their use. Therefore, this theory was used together with other theories to test whether the management accounting practices among manufacturing firms in Nigeria are determined by changes in their business environments.

\section{Institutional theory}

The extant literature reveals three branches of Institutional theory, comprising old institutional economy theory (OIE), new institutional theory, and new institutional sociology [29]. Using old institutional economy theory, researchers such as [13] have captured the issues of the coalition and competing values in organizational practices such as management accounting along with power and informal accountability structure.

The formal versus informal change perspective, which is one of the three dichotomies of OIE, was used in this study as it is the most suitable perspective for explaining the relationship between the variables of the study [13]. Mat [37] states that formal changes imply changes that are not explicitly directed, while the informal changes evolve from the intended actions of the people who enact and reproduce organizational routines. According to Mat [37], change is not a uniform phenomenon; it may come in the form of alterations of the existing management accounting practices, replacement, or substitution. When business firms respond to changes in their business environment, they are faced with the choices of which ones of the many management methods, techniques and systems would be most effective [37].

The exploration of issues of power and trust is affording more in-depth insight into the process of management accounting change. Some authors have earlier used the framework of Burns and Scapens [13] to explain how trust and distrust affect changes in management accounting practices [42]. Robalo [53] suggests that the issue of trust and power should be examined simultaneously and not separately. He also suggests that the influence of external pressure or internal pressure or lack of them on management accounting change should be considered through time and not at the initial stage only.

\section{Firm Culture}

Firm culture is the total values, codes, meanings, norms, and expectations capable of unifying a group of people working together [12]. The study carried out by Simionescu and Bică [54] revealed that Information systems and management accounting common forms are similar in different countries of Europe. Still, their associated management practices differ from country to country as a result of individual culture. Firms cultures have various dimensions including innovative culture, peopleoriented culture, outcome-oriented culture, aggressive culture, attention to details culture, team-oriented culture and stable culture (O'Reilly et al. [44].

\section{Innovation/risk orientation culture}

According to O'Reilly et al. [44], companies with innovation culture are flexible, adaptable, take risks, and experiment with new ideas. The firms in this category are flexible and have a flat hierarchy in which ranks and seniority are not emphasized, hence they tend to use modern management accounting practices more than firms without innovation/risk orientation culture [17]. In the same vein, Pasch [49] established a positive correlation between innovation and modern management accounting practices, and Charaf and Bescos [14] found explicitly that innovation culture has a significant effect on the adoption of activity-based costing (ABC). Therefore, the following hypothesis is stated.

$\mathbf{H}_{\mathbf{0}} \mathbf{1}$ Increased emphasis on innovation culture does not significantly affect the choice of management accounting practices among manufacturing firms in Nigeria.

\section{People-oriented culture}

People-oriented cultures emphasize justice, collaboration, and reverence for individual rights. Companies in this category see employees as their most significant resources and create a conducive working environment that would make employees feel at home at work and make them see work as fun and not as burdens [47]. Therefore, the study states the following hypothesis:

$\mathbf{H}_{0} 2$ Increased emphasis on people-oriented culture does not significantly affect the choice of management accounting practices among manufacturing firms in Nigeria.

\section{Team work culture}

Companies with team-oriented cultures are collaborative and emphasize cooperation among employees [51]. Charaf and Bescos [14] and Rababah [51] established that team-based culture does not significantly affect MAPs. However, Baird et al. [6] empirically established an association between team orientation culture and practice of activity-based costing while Deem et al. [18] also found a relationship between involvement culture (team-based) and practice of balanced scorecard. Likewise, Yigitbasioglu [61] states that a team-based organizational culture that trains and empowers workers may lead to new management accounting practices. Therefore, the following hypothesis is formulated:

$\mathbf{H}_{\mathbf{0}} 3$ Increased emphasis on Team-Oriented culture does not significantly affect the choice of management 
accounting practices among manufacturing firms in Nigeria.

\section{Attention to details culture}

Firms with attention to details culture emphasize precision and paying attention to details [51]. Charaf and Bescos [14] established that attention to details culture does not influence the choice of management accounting practices, while Rababah [51] argued otherwise. Therefore, the study proposes the hypothesis below:

$\mathbf{H}_{0} 4$ Increased emphasis on attention to details culture does not significantly affect the choice of management accounting practices among manufacturing firms in Nigeria.

\section{Stability culture}

Stable cultures are characterized by bureaucracy, predictability, and laid down rules. They harmonize and align employees' efforts for optimum productivity. A stable environment is void of uncertainty and may improve the effectiveness of the organization by providing steady and persistent levels of production [60]. But this type of culture is not flexible and is resistant to changes and innovation [47]. The extant literature reveals that firms with top managers reflecting flexibility values tend to use more advanced MAPs than those reflecting control values [43]. New management accounting techniques are innovations, and it is not clear whether the stability culture resists its practices or not. Therefore, this study tests the following hypothesis:

$\mathbf{H}_{0} \mathbf{5}$ Increased emphasis on stability culture does not have a significant effect on the choice of management accounting practices among manufacturing firms in Nigeria.

\section{Outcome-oriented culture}

The outcome-oriented culture places emphasis on accomplishment, outcomes, and activities as fundamental values [47]. Brandt-Siemers [11] established that corporate culture affects management accounting practices as the expected contribution and other benefits from the adoption determine whether a new practice would be accepted or not. Baird et al. [7] and Charaf and Bes$\cos$ [14] also established that outcome orientation culture influences new management accounting practices, but Rababah [51] could not establish any relationship between the two. Therefore, the study formulates the following hypothesis:

$\mathbf{H}_{0} \mathbf{6}$ Increased emphasis on outcome orientation culture does not significantly affect the choice of management accounting practices among manufacturing firms in Nigeria.

\section{Aggressive culture}

Firms having this culture emphasize competition and having the edge over the competitors. They may even do this at the expense of corporate social responsibility [47]. Nagirikandalage and Binsardi [39] posit that a sluggish approach to costing and cultural values are prominent barriers to the implementation of new MAPs. New management accounting practices are designed to support competitive strategy and improve performance $[9,10]$. Therefore, the following hypothesis is formulated:

$\mathbf{H}_{0} 7$ Increased emphasis on aggressive culture does not have a significant influence on the choice of management accounting practices among manufacturing firms in Nigeria.

\section{Empirical review}

Pasch [49] used a structural equation model to analyze the survey data collected from 244 firms from Germanspeaking countries and found out that Innovation and management accounting practices are positively correlated. In like manner, Brandt-Siemers [11] established that organizational culture affects the implementation of activity-based costing in the USA as managers are motivated by the need to understand the contribution margins and a desire to overcome the limitations of the budget and to make data-driven decisions.

To explore how MAPs are shaped through the interplay between the parent company culture and localization needs in Sri Lanka, Kapiyangoda [32] adopted the singlesite case study approach under the qualitative tradition. The findings show that given the complex set of being encountered with multiple cultural ramifications, MAPs of Delta Lanka show how imposed practices in the institutional environment by the parent company affect the MAPs in the company.

Likewise, Nagirikandalage and Binsardi [39] studied the implementation of cost accounting systems (CAS) using content analysis to examine the impact of Sri Lankan cultural and local characteristics on the adoption of CAS. The study revealed that inadequate access to information and the orientation of the local culture had affected the implementation of CAS in Sri Lanka, with a lack of awareness of the importance of CAS, a sluggish approach to costing and cultural values forming prominent barriers to its implementation.

Similarly, a mixed-method research strategy was adopted, including questionnaires survey and one-to-one interviews to shed some light on the interaction effect 
of MAPs and integrated information systems on organizational performance. The outcome of binary logistic regression analyses indicates that decentralized structure and corporate culture are barriers to the adoption of MAPs. The study revealed organizations with top managers reflecting flexibility values tend to use more advanced MAPs than those reflecting control values [43].

The study of Ominunu [46] shows that the firms cultures in Nigeria do not welcome the adoption and use of MAPs. The study examined the effect of management information and accounting system on the performance of organizations in Nigeria. Multistage and convenient sampling techniques were used to select one hundred (100) participants for the study. Data were collected via a questionnaire instrument, and Spearman's correlation and binary logistic regression were used for analysis. The results of the study showed that the cultures of organizations in Nigeria slow down the adoption and practice of new management accounting techniques.

Charaf and Bescos [14] also established that firm culture significantly influences management accounting practices in Morocco. Data were collected from the management of the 350 largest companies in the country as ranked by the Moroccan Kompass 2007. Ninety-eight of them were not useful, so the authors sent a questionnaire to only 301 companies via emails and got 62 responses for the analysis after three follow-ups by email, phone, and fax. The authors also conducted three semi-structured interviews with Moroccan cost controllers from different organizations. The four cultural dimensions that were tested include attention to details, Outcome-oriented culture, and team-based culture and Innovative culture. Adoption of activity-based costing ( $\mathrm{ABC}$ ) was based on yes or no answers. Using logistic regression, they established that innovation culture and outcome orientation culture have a significant effect on the adoption of $A B C$. In contrast, attention to details and team-based cultures do not have a substantial impact on the implementation of $\mathrm{ABC}$.

Deem et al. [18] likewise investigated the relationship between firm culture and the effectiveness of a balanced scorecard in the USA. The study was carried out among 1815 staff who had access to the county's BSC administration software out of 30,000 employees of one of the 10 -most populated counties that had implemented balanced scorecard (BSC). The questionnaire comprising 70 questions was sent to the respondents' email addresses. Organizational culture was broken down into four traits, including; involvement, consistency, adaptability, and mission. Descriptive statistics, analysis of variance (ANOVA), and correlation analysis, and Kruskal-Wallis analysis of variance were used to analyze the data. The statistical analysis of survey results confirmed that the four cultural dimensions, including involvement, consistency, adaptability, and mission, have a positive link with BSC effectiveness.

In a study conducted by Rababah [51] among the manufacturing companies in Jordan, it was established that some dimensions of culture affect the choice of management accounting practices, while some do not. The questionnaire survey was sent to 366 financial managers/ assistant financial managers via postal and monitored via telephone conversations. All the four cultural dimensions were measured on 5-point Likert scales 1-5 ranging from "not valued at all" to "valued to a very great extent" while balanced scorecard (BSC) implementation was measured on yes or no. Innovation culture indicators include: a willingness to experiment, not being constrained by many rules, being quick to take advantage of opportunities, being innovative, risk-taking, and being aggressive. Outcome orientation culture indicators include: being competitive, being achievement-oriented, having high expectations for performance, being results-oriented, and being action-oriented. Team Orientation culture indicators include: being people orientated, being teamorientated, and working in collaboration with others. Attention to details culture indicators comprises: paying attention to details, being precise and being careful. The analysis of 225 useful responses via logistic regression revealed that outcome orientation culture and team orientation culture have no significant effect on the implementation of BSC. In contrast, innovative culture and attention to details have a substantial impact on BSC implementation.

Similarly, Kevin et al. [33] established that in Australia, teamwork/respect for people culture is an essential factor in enhancing the use of MAPs, while outcome-oriented and innovative cultures came next. In like manner, Naranjo-Valencia et al. [41] empirically established that flexible culture is a clear determinant of innovation strategy while rigid cultures promote imitation.

The accounting system has been heavily criticized by many authors. Empirical work of Budi and Nusa [12] also indicates the significant influence of organizational culture on the quality of accounting information systems, while Chenhall et al. [15] establish an association between innovative culture and management accounting practices.

\section{Methods}

This study employed a survey research design to investigate the effect of culture on management accounting practices. Mat [37] states that survey research can be used for description and explanation. Moreover, Mat [37] expounds that descriptive studies are designed to discover characteristics of a given population, not to test the 
theory, but explanatory studies can be used to test theories. In management accounting research, surveys are most commonly used for explanation, that is, to test the theory that states the expected effects of some particular variables over the others. Furthermore, the survey can be cross-sectional or longitudinal, and the longitudinal survey can be repeated or a one-time survey. A one-time survey, also known as a retrospective longitudinal survey, is used for this study. Besides, repeated surveys are often reported of incomplete data due to decreasing responses over time [57]. Also, a retrospective longitudinal survey has been successful in management accounting research as established in earlier studies [5, 16, 31, 36, 37].

The research instrument developed by O'Reilly et al. [44] was adapted to measure the seven dimensions of firm culture on a 5-point summated Likert scale. The respondents were asked to indicate the level of the emphasis on their firm culture over five years (2011-2015) on a 5-point Likert scale ranging from "Significantly less emphasized"(1) to "Significantly emphasized"(5).In the same manner, management accounting practices were measured by asking respondents on the level of use of 15 modern management accounting techniques over five years (2011-2015) on a 5-point summated scale ranging from "Never used"(1) to "Very frequently used"(5). Year frame 2011-2015 was chosen to capture the transformation agenda (the economic plan of Nigeria to achieve vision 20: 2020) toward improving the manufacturing sector of Nigeria and make Nigeria becomes one of the first 20 productive nations by the year 2020 . Modern management accounting techniques alone were used to proxy management accounting practices since they are useful for determining traditional management accounting practices and advanced management accounting practices as non-users of modern techniques can be regarded as users of traditional techniques [31]. After the factor analysis, only 12 management accounting techniques were subjected to the regression analysis. The average of the sum score was calculated, and those firms that fall below average in their use of modern management accounting techniques are categorized as firms using traditional management accounting techniques while firms that scored above average in their usage of modern management accounting techniques are categorized as firms using modern management accounting techniques. Ninety-seven firms eventually fall under the label "modern management accounting practices," while 75 firms fall under "traditional management accounting practices." Since categories are only two and not ranked, logistic regression is deemed appropriate. The modern management accounting techniques are scored 1 , while the traditional management accounting (non-user of modern management accounting techniques) is scored 0.
The questionnaire was first of all pretested with 15 companies, after which it was personally handed over to Management Accountants/Finance controller/Head of account units of 220 companies randomly selected from the main directory of the Manufacturers Association of Nigeria. One hundred eighty-nine copies (189) were returned by the respondents, but 17 of them were incomplete, leaving the authors with 172 valid instruments for the analysis. Out of 514 manufacturing firms, the sample size of 220 arrived using a precision method. According to Kothari and Garg [34], the sample size of a finite population can be determined as follows:

$$
n=\frac{z^{2} \cdot p \cdot q \cdot N}{e^{2}(N-1)+z^{2} \cdot p \cdot q}
$$

where $N=$ size of population; $n=$ size of sample; $e=$ acceptable error (the precision) at $95 \%$ confidence interval; $p=$ standard deviation of population at $95 \%$ confidence interval or sample proportion which is assumed to be .5; $q=1-p ; z=$ standard variate at a given confidence level.

$$
\begin{aligned}
& n=\frac{1.96^{2} \times 0.5 \times 0.5 \times 514}{0.05^{2}(514-1)+1.96^{2} \times 0.5 \times 0.5} \\
& n=534 \\
& 1.3875+0.9604 \\
& n=494=220 \\
& 2.2429
\end{aligned}
$$

\section{Model specification}

The sum scores of management accounting techniques were determined, and the average was found. The score below average, which represents non-users of modern MAPs was classified as traditional MAPs and coded "0," while the score above average was classified as modern MAPs and coded "1." Seven firms' cultural dimensions were used and regressed against MAPs. Since the study is investigating the influence of culture on the choice of MAPs and MAPs is a categorical variable, logistic regression model indicating a linear relationship between firm culture and management accounting practices is stated in Eq. 2

$$
\begin{aligned}
\ln \text { odds }= & \beta_{0}+\beta_{1} \mathrm{ICC}+\beta_{2} \mathrm{ORC}+\beta_{3} \mathrm{POC}+\beta_{4} \mathrm{AC} \\
& +\beta_{5} \mathrm{SC}+\beta_{6} \mathrm{ADC}+\beta_{7} \mathrm{TWC}
\end{aligned}
$$

where $\beta_{0}=$ constant; $\beta_{1}-\beta_{7}=$ coefficients of the independent variables; $\mathrm{ICC}=$ innovation culture; $\mathrm{ORC}=$ outcome orientation culture; $\mathrm{POC}=$ people orientation culture; $\mathrm{AC}=$ aggressive culture; $\mathrm{SC}=$ stability culture; 
$\mathrm{ADC}=$ attention to details culture; $\mathrm{TWC}=$ teamwork culture.

\section{Results and discussion}

The study used both descriptive and inferential statistics. The outcomes of the descriptive statistics are discussed below.

\section{Descriptive analysis}

Mean, mode, and standard deviation were used to analyze the firm culture and management accounting practices in Nigeria.

\section{Management accounting practices}

This study found out that manufacturing companies in Nigeria practice some modern management accounting techniques during the period. The techniques include: activity-based costing, activity-based budgeting, and activity-based management, target costing, quality costing, product profitability analysis, value chain analysis, and benchmarking. The results in Table 1 show that life cycle costing, just in time, throughput accounting, backflush costing, balanced scorecard, and kaizen costing were not practiced during the period. This result lends credence to the findings of Oyerogba [48] that manufacturing companies in Nigeria have not been practicing balanced scorecard and activity-based management.

\section{Firm culture by manufacturing companies in Nigeria}

Similarly, Firm culture was measured in seven dimensions, including innovation/risk orientation, emphasis on outcome, and emphasis on people, aggressiveness, attention to details, teamwork, and stability. The mean index of 4 (rounded up to the nearest whole number) implies that, on average, manufacturing companies in Nigeria emphasized all the above elements of firms' culture. The mode means that innovation/risk orientation, emphasis on outcome, and stability were significantly emphasized, while emphasis on people and aggressiveness was just emphasized. The standard deviation of 1 (rounded up to the nearest whole number) also implies that the answers of the respondents spread between "No change" and "strongly emphasized" ( $4-1=3$ and $4+1=5)$ (Table 2).

\section{Inferential analysis}

The research data were, first of all, subjected to confirmatory factor analysis using principal component analysis and a threshold of 4.0.12 out of 15 management accounting techniques that were subjected to factor analysis met the benchmark of 4.0 and were subjected to further analysis. Principal component method of factor analysis was used because its factor loading explains more variance than the factor loadings of any other methods [35]. This study adopts a threshold of .4-factor loading as argued by Pituch and Stevens [50] that a cut-off of .4, irrespective of sample size, is better for interpretative purposes. Both the MAPs and firm culture were also subjected to reliability tests using Cronbach's alpha, and their scores exceed .7.

\section{Influence of firm culture on management accounting practices}

This section examined the overall influence of firm culture on MAPs. The $p$ value which is below .05 in Table 1 implies that the model is fit (Table 3).

Similarly, Nagelkerke R-square, which is .382, implies that the model contributes about $38 \%$ variations in management accounting practices. However, it should be

Table 1 Descriptive statistics for management accounting practices

\begin{tabular}{|c|c|c|c|c|c|c|c|c|}
\hline & \multirow{2}{*}{$\begin{array}{l}\text { Never used } \\
\text { Row } N \%\end{array}$} & \multirow{2}{*}{$\begin{array}{l}\text { Rarely used } \\
\text { Row } N \%\end{array}$} & \multirow{2}{*}{$\begin{array}{l}\text { Not sure } \\
\text { Row } N \%\end{array}$} & \multirow{2}{*}{$\begin{array}{l}\text { Frequently used } \\
\text { Row } N \%\end{array}$} & \multirow{2}{*}{$\begin{array}{l}\text { Very Freq used } \\
\text { Row } N \%\end{array}$} & \multicolumn{3}{|c|}{ Subtotal } \\
\hline & & & & & & Mean & Mode & Sd \\
\hline$A B C$ & 3.5 & 5.2 & 2.3 & 68.0 & 20.9 & 3.98 & 4 & .87 \\
\hline$A B B$ & 2.3 & 16.4 & 4.7 & 41.5 & 35.1 & 3.91 & 4 & 1.12 \\
\hline ABM & 1.7 & 20.3 & 4.7 & 48.8 & 24.4 & 3.74 & 4 & 1.10 \\
\hline Target costing & 1.2 & 19.8 & 22.1 & 34.3 & 22.7 & 3.58 & 4 & 1.08 \\
\hline Life cycle costing & 7.0 & 19.9 & 29.8 & 28.1 & 15.2 & 3.25 & 3 & 1.15 \\
\hline Quality costing & 2.3 & 24.0 & 8.8 & 40.9 & 24.0 & 3.60 & 4 & 1.16 \\
\hline Just in time & 2.9 & 31.6 & 18.7 & 33.3 & 13.5 & 3.23 & 4 & 1.12 \\
\hline TA & 8.1 & 11.6 & 27.9 & 35.5 & 16.9 & 3.41 & 4 & 1.14 \\
\hline Backflush costing & 4.7 & 15.2 & 34.5 & 28.1 & 17.5 & 3.39 & 3 & 1.09 \\
\hline Balanced score card & 3.5 & 30.2 & 16.3 & 31.4 & 18.6 & 3.31 & 4 & 1.19 \\
\hline Kaizen costing & 14.5 & 32.0 & 22.1 & 26.2 & 5.2 & 2.76 & 2 & 1.15 \\
\hline Value chain analysis & 3.5 & 12.8 & 9.9 & 59.3 & 14.5 & 3.69 & 4 & .99 \\
\hline
\end{tabular}


Table 2 Statistics of firm culture emphasized by manufacturing companies in Nigeria during $2011=2015$

\begin{tabular}{|c|c|c|c|c|c|c|c|c|c|}
\hline & \multirow{2}{*}{$\begin{array}{l}\text { SLE } \\
\text { Row } N \%\end{array}$} & \multirow{2}{*}{$\begin{array}{l}\text { LE } \\
\text { Row } N \%\end{array}$} & \multirow{2}{*}{$\begin{array}{l}\text { NC } \\
\text { Row N\% }\end{array}$} & \multirow{2}{*}{$\begin{array}{l}\mathrm{E} \\
\text { Row } N \%\end{array}$} & \multirow{2}{*}{$\begin{array}{l}\text { SE } \\
\text { Row N\% }\end{array}$} & \multicolumn{4}{|l|}{ Subtotal } \\
\hline & & & & & & Row $N \%$ & Mean & Mode & SD \\
\hline Innovation/risk orientation & 3.5 & 7.6 & 10.5 & 34.9 & 43.6 & 100.0 & 4.08 & 5 & 1.08 \\
\hline Emphasis on outcome & 2.9 & 9.3 & 12.2 & 30.2 & 45.3 & 100.0 & 4.06 & 5 & 1.10 \\
\hline Emphasis on people & 1.7 & 2.3 & 8.1 & 53.5 & 34.3 & 100.0 & 4.16 & 4 & .81 \\
\hline Aggressiveness & 6 & 7.6 & 7.6 & 42.4 & 41.9 & 100.0 & 4.17 & 4 & .91 \\
\hline Stability & .6 & 5.2 & 11.0 & 40.7 & 42.4 & 100.0 & 4.19 & 5 & .87 \\
\hline Attention to details & 1.6 & 2.5 & 13.1 & 40.2 & 42.6 & 100.0 & 4.18 & 5 & .98 \\
\hline Teamwork & 2.3 & 8.4 & 15.2 & 39.1 & 35.0 & 100.0 & 4.15 & 4 & .85 \\
\hline
\end{tabular}

SLE strongly less emphasized; $L E$ less emphasized; $N C$ no change, $E$ emphasized, $S E$ strongly emphasized

Table 3 Overall Omnibus tests of model coefficients

\begin{tabular}{lllll}
\hline & & Chi-square & Df & Sig. \\
\hline Step 1 & Step & 57.631 & 7 & .000 \\
& Block & 57.631 & 7 & .000 \\
& Model & 57.631 & 7 & .000 \\
\hline
\end{tabular}

borne in mind that Nagelkerke R-square and Cox and Snell R-square are pseudo-R-square; they are usually low, so they should be taken with cautions. The closer the $-2 \log$-likelihood to 0 , the better the fitness of the model; however, it is difficult to interpret since it has no maximum [23]. It can, however, be interpreted by comparing the individual -2 log-likelihood with $-2 \log$ likelihood when other variables are added to the model; if the value for $-2 \log$-likelihood when other variables are added to the model is lower than the individual $-2 \log$ likelihood, then the model is fit [23]. Since the overall -2 log-likelihood, which is 177.990 , is lower than individual -2 log-likelihood 231.335 for innovation culture in Table B in "Appendix 2," it means the variable adds value to the model. In like manner, since the overall -2 Loglikelihood is lower than - 2LL of 233.855 for outcome orientation culture, in Table F, "Appendix 2," it means the variable contributes to the model. Similarly, since the total -2LL is below 235.172 for people orientation culture, in Table J, "Appendix 2," it means the variable is needed in the model. Likewise, in as much the overall $-2 \mathrm{LL}$ is less than 231.398 for aggressive culture in Table $\mathrm{N}$, "Appendix 2," the indication is that the variable is unique to the model. In the same vein, the overall $-2 \mathrm{LL}$, which is less than 222.665 for stability culture in Table $\mathrm{R}$ "Appendix 2," means that the factor contributes to the model. Also, - 2LL of 211.788 for attention to details culture and 222.399 for teamwork culture) in Tables $\mathrm{V}$ and $Z$, respectively, in "Appendix 2," which are higher than the overall $-2 L L$ imply that the model could be considered fit (Table 4).
Table 4 Overall model summary

\begin{tabular}{llll}
\hline Step & $\mathbf{- 2}$ Log-likelihood & $\begin{array}{l}\text { Cox and Snell } \boldsymbol{R} \\
\text { square }\end{array}$ & $\begin{array}{l}\text { Nagelkerke } \boldsymbol{R} \\
\text { square }\end{array}$ \\
\hline 1 & $177.990^{\mathrm{a}}$ & .285 & .382 \\
\hline
\end{tabular}

Table 5 Overall model classification table

\begin{tabular}{|c|c|c|c|c|c|}
\hline & \multirow[t]{3}{*}{ Observed } & & \multicolumn{3}{|c|}{ Predicted } \\
\hline & & & \multicolumn{2}{|c|}{ MAPs } & \multirow{2}{*}{$\begin{array}{l}\text { Percentage } \\
\text { correct }\end{array}$} \\
\hline & & & 0 & 1 & \\
\hline \multirow[t]{3}{*}{ Step 1} & MAP & 0 & 50 & 25 & 66.7 \\
\hline & & 1 & 20 & 77 & 79.4 \\
\hline & Overall Percentage & & & & 73.8 \\
\hline
\end{tabular}

In like manner, Table 5 shows that $66.7 \%$ of traditional MAPs were correctly classified, $79.4 \%$ of the modern MAPs were correctly classified, while the overall percentage of correct classification was $73.8 \%$. This implies that the model contributes about a $74 \%$ variation in management accounting practices.

\section{The influence of innovation culture on management accounting practices}

Table 6 shows that innovation culture is likely to contribute $41.9 \%$ changes in management accounting practices. It implies that an increased emphasis on innovation culture is expected to increase the usage of modern MAPs by $41.9 \%$. This analysis also established this finding by Exp (B), also known as an odds ratio, which indicates that an increased emphasis on innovation culture leads to an increased usage of modern management accounting practices. It means that the higher the emphasis on innovation culture, the higher the likelihood of choosing modern MAPs by manufacturing firms in Nigeria. In other words, innovation culture is likely to cause firms to 
Table 6 Overall variables in the equation

\begin{tabular}{llllllll}
\hline & B & S.E. & Wald & df & Sig. & Exp (B) \\
\hline Step $1^{\text {a }}$ & Teamwork & -.918 & .272 & 11.396 & 1 & .001 & .399 \\
& Innovation & .419 & .257 & 2.651 & 1 & .103 & .000 \\
& Attention & -1.298 & .291 & 19.894 & 1 & .273 \\
Outcome & .008 & .234 & .001 & .973 & 1.008 \\
& People & .251 & .255 & .969 & 1 & .325 & .302 \\
& Aggressive & .267 & .258 & 7.067 & 1 & 1.286 \\
Stability & .625 & 1.174 & 3.082 & 1 & .008 & .079 \\
\hline
\end{tabular}

a Variable(s) entered on step 1: Teamwork, Innovation, Attention, Outcome, People, Aggressiveness, Stability

choose modern management accounting practices 1.420 times than it causes them to choose traditional management accounting practices. This result lends credence to the assertion of an earlier author that innovation orientation, innovation support, or flexibility value tend to use modern management accounting practices more than firms without such culture [17]. However, the $p$ value of .103 implies that the effect of innovation on the choice of management accounting practices is not significant at $5 \%$ level of significance. This finding contradicts the findings of Charaf and Bescos [14] and Rababah [51], who established that innovation culture has a significant effect on the adoption of modern MAPs. Therefore, the hypothesis one of this study, which states that "Increased emphasis on innovation culture does not have a significant influence on the choice of management accounting practices among manufacturing firms in Nigeria," is now accepted.

\section{The influence of people-oriented culture on management accounting practices}

In like manner, Table 6 shows that holding other factors constant, the increased emphasis on people orientation culture causes $25.1 \%$ changes in management accounting practices and that increased emphasis on people orientation culture leads to an increased usage of modern management accounting practices. This result is also established by the odds ratio, which indicates that the higher the emphasis on People-oriented culture, the higher the likelihood of using modern management accounting practices. This finding lends support to contingency theory that there are no best MAPs, but it all depends on the situation on the ground, which includes the culture of the firm. However, the influence of peopleoriented culture on management accounting practices is not significant at $5 \%$ level of significance. Therefore, hypothesis 2 of this study, which states that "peopleOriented culture does not have a significant effect on the choice of management accounting practices," is as a result of this accepted.
It is a surprise that firms having a people-oriented culture that sees people as their greatest asset [47, p 645] do not support modern management accounting practices. The qualities of People-oriented cultures in terms of justice, supportiveness, and respect for individual rights go a long way in determining the success of any firm. It implies that modern management accounting practices do not significantly support those values. This result lends credence to contingency theory which states "there is no universally appropriate accounting system applying equally to all organisations in all circumstances" [22, p 57].

\section{The influence of team-based culture on management accounting practices}

Similarly, Table 6 suggests that increased emphasis on team-based culture is likely to reduce the choice of modern management accounting practices by $91.8 \%$. This result is supported by an odds ratio (.399), which is less than 1. It implies that the higher the emphasis on teambased culture, the lower the likelihood of choosing modern management accounting practices. This effect of team-based culture on management accounting practices is statistically significant at a $5 \%$ level of significance. Therefore, hypothesis 3 of this study, which states that "Increased emphasis on Team-Oriented culture does not have a significant influence on the choice of management accounting practices among manufacturing firms in Nigeria," is with this rejected.

This finding, however, contradicts the findings of Charaf and Bescos [14] and Rababah [51], who established that teamwork culture has no relation with the modern management accounting practices in Morocco and Jordan, respectively. Nevertheless, the finding lends credence to the results of Deem et al. [18], who found out that involvement culture(teamwork culture) influences the choice of management accounting practices in the USA. 


\section{Influence of attention to details culture on management accounting practices}

In the same vein, Table 6 implies that increased emphasis on attention to details culture by manufacturing firms in Nigeria reduces the likelihood of choosing modern management accounting practices by $129.8 \%$. It implies that attention to details culture considerably determines management accounting practices at a 5\% level of significance. Therefore, hypothesis 4 of this study, which states that "Increased emphasis on attention to details culture does not have a significant influence on the choice of management accounting practices among manufacturing firms in Nigeria," is hereby rejected.

This result supports the findings of Rababah [51], who also established that attention to details culture influences the choice of MAPs in Jordan. However, it contradicts the findings of Charaf and Bescos [14], who found no association between attention to details culture and management accounting practices.

\section{The influence of stability culture on management accounting practices}

Likewise, Table 6 shows that as the firms increased emphasis on stability culture, the likelihood of using modern management accounting practices increases by $62.5 \%$. This outcome is supported by the odds ratio, which implies that the higher the emphasis on stability culture, the higher the likelihood of choosing modern management accounting practices. The result indicates that firms emphasizing stability culture are more likely to choose modern MAPs than traditional MAPs. The $p$-value of .001 implies that stability culture significantly influences the choice of management accounting practices. Therefore, hypothesis 5 of this study, which states that "Increased emphasis on stability culture does not have a significant influence on the choice of management accounting practices among manufacturing firms in Nigeria," is hereby rejected. This finding lends credence to the old institutional economy theory that formal and informal change in the business environment can influence the choice of management accounting practices. As the manufacturing firms in Nigeria increased emphasis on stability culture, it causes an alteration in their choice of management accounting practices.

This result contradicts the prior expectation of the literature that stable cultures do not support innovations because they are predictable, rule-oriented, and bureaucratic. In an unchanging environment, stable cultures may help the organization be effective by providing steady and continuous levels of production [60]. These cultures may be a misfit to a dynamic environment as they prevent swift action. However, practical cases have shown that when the bureaucracy is preventing the organization from taking advantage of the innovation, such bureaucracy can be fought with more bureaucracy as it happened in the case of Kraft Food Inc [56]. When it was observed that its bureaucratic culture is killing good ideas in early stages and preventing the company from innovating, one of their first actions was to fight bureaucracy with more bureaucracy by creating the new position for the Assistant Head of business process simplification, which was later eliminated $[55,56]$.

Also, the issue of trust and power cannot be overemphasized in bureaucratic settings. When the CEO and other managers have confidence in the management accountants, they accept the innovation in management accounting practices more quickly than when they have distrust $[13,53]$. The findings of Robalo [53] established that the trust that the management of National postal service of Portugal had in the management accountants made them accept the new management accounting practices easily, but the power for full implementation lies in the hand of planning and control office which created a gap from making the new rule a routine. It was also noted that when the new law is consistent with the existing rule but just an extension from it, it is readily accepted than when the new rule challenges the existing rule. Robalo [53] established that new management accounting practices are an extension of traditional practices. Even in a situation where the new rule challenges the existing rule, the study of Ribeiro and Scapens [52] shows that there is an alternative explanation. They established that even though the innovation introduced into the organization challenged the regular routines and institutions, it was not rejected and has been kept in place by power issues. Therefore, according to the old institutional theory, the trust and power issues may cause the management to shift ground from the existing rules and routine for the new rules. It means that the confidence of the Management of the manufacturing firms in Nigeria in new MAPs or Management Accountants or whoever introduces new MAPs to them make them adopt the new MAPs and use their power to subdue the bureaucracy, existing rules, and routine.

\section{Influence of outcome-oriented culture on management accounting practices}

Although the coefficient of the equation in Table 6 shows that the increased emphasis on outcome orientation culture causes $.8 \%$ (less than $1 \%$ ) changes in management accounting practices, the odds ratio implies that the increased focus on outcome orientation culture leads to an increased usage of modern management accounting practices. However, the effect of outcome-oriented culture on management accounting practices is not significant at 5\% level of significance. Therefore, hypothesis 6 of this study, which states that "Increased emphasis on 
outcome orientation culture does not significantly affect the choice of management accounting practices among manufacturing firms in Nigeria," is hereby not rejected.

This finding contradicts the findings of Baird et al. [6], who found out that outcome orientation culture is significantly associated with the implementation of activitybased costing in Australia. It also contradicts the findings of Charaf and Bescos [14], who equally established a relationship between outcome orientation culture and implementation of a balanced scorecard in Morocco. It, however, supports the findings of Rababah [51] that outcome orientation culture has no significant effect on the implementation of a balanced scorecard in Jordan.

\section{Aggressive culture and management accounting practices}

Finally, Table 6 implies that increased emphasis on aggressive culture contributes a $26.7 \%$ increase in management accounting practices and causes firms to use modern management accounting practices in 1.306 times than it causes them to use traditional management accounting practices. However, the effect of aggressive culture on management accounting practices is not significant at $5 \%$ level of significance. Therefore, hypothesis 7 of this study, which states that "Increased emphasis on aggressive culture does not have a significant influence on the choice of management accounting practices among manufacturing firms in Nigeria," is hereby accepted.

Amazingly, firms having aggressive culture did not implement modern management accounting practices. The reason is that modern management accounting practices are believed to improve performance by providing more sophisticated information, and firms having aggressive culture are after the performance, and they are ready to outperform their competitors at all costs [47]. Considering the benefits of modern management accounting practices, they quickly embraced the new techniques that can enhance their achievement.

Based on the above results, the model is re-stated as follows:

$$
\begin{aligned}
\text { MAPs }= & 2.060+0.419 \mathrm{ICC}+0.008 \mathrm{ORC} \\
& +0.251 \mathrm{POC}+0.67 \mathrm{AC}+0.625 \mathrm{SC} \\
& -1.298 \mathrm{ADC}-0.918 \mathrm{TWC}
\end{aligned}
$$

where $\mathrm{MAPs}=$ management accounting practices; ICC $=$ Innovation Culture; ORC $=$ outcome orientation culture; $\mathrm{POC}=$ people orientation culture; $\mathrm{AC}=$ aggressive culture; $\mathrm{SC}=$ stability culture; $\mathrm{ADC}=$ attention to details culture; $\mathrm{TWC}=$ teamwork culture.

\section{Summary of findings}

The study has established that the choice of management accounting practices is contingent upon some cultural values. Specifically, the study established the significant influence of Teamwork culture, attention to details culture and stability culture on the choice of MAPs. However, the study reveals that the increased emphasis on Teamwork and attention to details cultures significantly reduces the usage of management accounting practices. Even though the effect of innovation/risk orientation culture, people orientation culture, outcome orientation culture, and aggressive culture is not statistically significant, their odd ratios indicate that they increase the usage of MAPs. Despite the attached benefits of modern MAPs, the study reveals that the organizational cultures of manufacturing firms in Nigeria do not considerably support the usage of modern MAPs. This finding lends credence to the contingency theory, which states that what constitutes effective management depends on the exclusive features of each situation (Woodward, 1980).

Similarly, the study revealed that stability culture has a positive and considerable influence on modern MAPs. This finding lends credence to the old institutional economy theory that formal and informal change in the business environment can influence the choice of management accounting practices. As the manufacturing firms in Nigeria increased emphasis on stability culture, it causes an alteration in their choice of management accounting practices.

\section{Conclusion}

This study has established that firm culture has a significant influence on the choice of management accounting practices. Only teamwork, attention to details, and stability cultures have considerable control over the selection of MAPs. Teamwork and attention to details culture may significantly influence the choice of management accounting practices as the firms emphasizing them are likely to use less modern MAPs. Even though the influences of innovation, people orientation, outcome orientation, and aggressive cultures on MAPs are not significant, the study has established that the more they are emphasized, the more likely modern MAPs are chosen. Stability culture has a significant influence on the choice of MAPs, and the more it is emphasized, the more likely the manufacturing firms in Nigeria choose modern MAPs.

Teamwork culture and attention to details culture are barriers to the implementation of modern management accounting practices among manufacturing firms in Nigeria. It is not everybody that will agree with you at all times regardless of the prospect of your vision. Some employees with strong personalities may not allow you to achieve your vision if you must wait for them. Likewise, focusing too strongly on little matters may jeopardize bigger and better opportunities. Therefore, managers of manufacturing firms in Nigeria should exercise caution and moderation on their teamwork and attention to details cultures. The 
management should lay more emphasis on innovation/risk orientation culture, people orientation culture, outcome orientation culture, aggressive culture, and stability culture. The focus on the cultures mentioned above will enable them to take advantage of better management accounting practices, which may subsequently improve their performances.

Therefore, this study recommends that manufacturing firms in Nigeria should be cautious of their culture and its implication on management accounting practices. In a more explicit term, they should practice cultures that will allow them to choose modern management accounting practices and take advantage of the benefits attached.

Future researchers may look at the combined effects of firm cultures and management accounting practices on their performances and also find out how management accounting practices intervenes between firm cultures and their achievements.

\begin{abstract}
Abbreviations
AC: aggressive culture; ACC: activity-based costing; $A D C$ : attention to details culture; ANOVA: analysis of variance; BSC: balanced scorecard; CAS: cost accounting system; CFO: chief finance officer; ICC: innovation culture; JMPS: Japanese style management and production system; MAPs: management accounting practices; OIE: old institutional economy theory; ORC: outcome orientation culture; POC: people orientation culture; SC: stability culture; TWC: teamwork culture; USA: United States of America.
\end{abstract}

\section{Acknowledgements}

We heartily appreciate Dr Tobias Olweny and Dr Oluoch Oluoch from Jomo Kenyatta University of Agriculture and Technology, Nairobi, Kenya, for their relentless efforts and insightful contribution during the supervision of the main project from which this study is carved out. Their thoughtful comments and advices go a long way in making the thesis a reality. We are greatly indebted to them for their availability, patience, and understanding. Many thanks are due to IAAER/ACCA workshop team on paper development that has significantly enhanced the quality of this work. The reviewers of the work Professor Catalin Albu Professor Nada Albu from Bucharest University,
Romania, and the Conference Chairman, professor Donna Street are greatly acknowledged for their valuable support. Also, the eye-opening contributions of Prof. Taiwo Asaolu and Prof.Salau from Obafemi Awolowo Univerity and Dr.(Mrs) Ajibolade from University of Lagos, Nigeria, cannot be over-emphasized in the success of this study. The contributions of various scholars during the 3rd International Conference of Accounting and Finance organized by ICAN and University of Lagos on April 19-21, 2016, are greatly appreciated.

\section{Authors' contribution}

The corresponding and co-authors contributed to this study. O.I initiated the study, collected data, and analyzed it. E.O tremendously contributed to theoretical review, empirical review, and hypotheses development. O.E also assisted in data analysis and proofread the whole manuscript and made corrections. The manuscript was agreed to be published after all the authors have proofread and approved the final version of the work.

\section{Funding}

The authors did not receive any fund for this study either from government or private sector.

\section{Compliance with ethical standards}

Competing interest

The authors declare that there is no competing interest.

\section{Availability of data and materials}

The datasets used and/or analyzed during the current study are available from the corresponding author on reasonable request. However, the research instrument for the study is included in the manuscript.

\section{Author details \\ ${ }^{1}$ Afe Babalola University Ado-Ekiti, Km 8.5, Afe Babalola Way, P.M.B. 5454, Ado-Ekiti, Ekiti State, Nigeria. ${ }^{2}$ Bowen University, Iwo, Osun State, Nigeria.}

\section{Appendix 1: research instrument}

\section{Firm culture}

The essence of this section is to find out the influence of firm culture on management accounting practices in your company. Please indicate the extent of the emphasis you have placed on the following organization cultures within the past 5 years $(2011-2015)$.

\begin{tabular}{|c|c|c|c|c|c|}
\hline Cultures & $\begin{array}{l}\text { Strongly } \\
\text { less emphasized }\end{array}$ & Less emphasized & No change & Emphasized & $\begin{array}{l}\text { Strongly } \\
\text { emphasized }\end{array}$ \\
\hline \multicolumn{6}{|l|}{$\begin{array}{l}\text { Innovation/Risk orientation. Emphasis on } \\
\text { employees to take risk and innovation in the } \\
\text { performance of their jobs }\end{array}$} \\
\hline \multicolumn{6}{|l|}{$\begin{array}{l}\text { Emphasis on Outcome. Focus on the result and } \\
\text { not on how results are achieved }\end{array}$} \\
\hline \multicolumn{6}{|l|}{$\begin{array}{l}\text { Emphasis on people. A great deal of impor- } \\
\text { tance on how management decisions would } \\
\text { affect the employees. People-oriented } \\
\text { cultures value fairness, supportiveness, and } \\
\text { respect for individual right }\end{array}$} \\
\hline \multicolumn{6}{|l|}{$\begin{array}{l}\text { Aggressiveness. Competitive orientation for } \\
\text { employees to outperform the competitors } \\
\text { at all cost }\end{array}$} \\
\hline \multicolumn{6}{|l|}{ Stability. Rule orientation, bureaucratic nature. } \\
\hline \multicolumn{6}{|l|}{$\begin{array}{l}\text { Attention to details. } \\
\text { Emphasize precision and paying attention to } \\
\text { details }\end{array}$} \\
\hline $\begin{array}{l}\text { Teamwork culture collaboration and emphasis } \\
\text { on cooperation among employees }\end{array}$ & & & & & \\
\hline
\end{tabular}




\section{Section B}

This section seeks information on changes in management accounting practices in your company over the past 5 years (2011-2015 inclusive). Please indicate the extent to which you have used the following management accounting techniques over the past 5 years.

\section{Modern management accounting practices}

\begin{tabular}{|c|c|c|c|c|c|c|}
\hline $\mathrm{S} / \mathrm{N}$ & Techniques & Never used & Rarely used & Not sure & Frequently used & Very frequently used \\
\hline 1 & Activity-based costing & & & & & \\
\hline 2 & Activity-based budgeting & & & & & \\
\hline 3 & Activity-based management & & & & & \\
\hline 4 & Target costing & & & & & \\
\hline 5 & Life cycle costing & & & & & \\
\hline 6 & Quality costing & & & & & \\
\hline 7 & Product profitability analysis & & & & & \\
\hline 8 & Just in time & & & & & \\
\hline 9 & Throughput accounting & & & & & \\
\hline 10 & Benchmarking & & & & & \\
\hline 11 & Backflush costing & & & & & \\
\hline 12 & Balanced scorecard & & & & & \\
\hline 13 & $\begin{array}{l}\text { Shareholders value analysis/ } \\
\text { economic value analysis }\end{array}$ & & & & & \\
\hline 14 & Kaizen costing & & & & & \\
\hline 15 & Value chain analysis & & & & & \\
\hline
\end{tabular}

\section{Appendix 2}

Table A: Omnibus tests of model coefficients on innovation culture and MAP

\begin{tabular}{llll}
\hline & Chi-square & Df & Sig. \\
\hline Step & 4.286 & 1 & .038 \\
Block & 4.286 & 1 & .038 \\
Model & 4.286 & 1 & .038 \\
\hline
\end{tabular}

Table B: Model summary for innovation culture

\begin{tabular}{lll}
\hline $\mathbf{- 2}$ Log-likelihood & Cox and Snell R-Square & Nagelkerke R-square \\
\hline $231.335^{\mathrm{a}}$ & .025 & .033 \\
\hline
\end{tabular}

Table C: Classification table for innovation culture

\begin{tabular}{lllll}
\hline Observed & \multicolumn{2}{l}{ Predicted } & \\
\cline { 3 - 4 } & & \multicolumn{2}{l}{$\begin{array}{l}\text { Percentage } \\
\text { MAPs }\end{array}$} & \\
\cline { 3 - 4 } & $\mathbf{0}$ & $\mathbf{1}$ & \\
\hline MAPs & 0 & 20 & 55 & 26.7 \\
& 1 & 17 & 80 & 82.5 \\
\multicolumn{2}{l}{ Overall percentage } & & & 58.1 \\
\hline
\end{tabular}

Table D: Variables in the equation for innovation culture

\begin{tabular}{llllllll}
\hline & & B & S.E. & Wald & Df & Sig. & $\operatorname{Exp(B)}$ \\
\hline Step 1 & Innovation & .381 & .186 & 4.190 & 1 & .041 & 1.464 \\
& Constant & -.525 & .411 & 1.632 & 1 & .201 & .591
\end{tabular}

Table E: Omnibus tests of model coefficients for outcome orientation culture

\begin{tabular}{lllll}
\hline & & Chi-square & Df & Sig. \\
\hline Step 1 & Step & 1.766 & 1 & .184 \\
& Block & 1.766 & 1 & .184 \\
& Model & 1.766 & 1 & .184 \\
\hline
\end{tabular}

Table F: Model summary for outcome orientation culture

\begin{tabular}{lll}
\hline $\mathbf{- 2}$ Log-likelihood & $\begin{array}{l}\text { Cox and Snell } \\
\text { R-square }\end{array}$ & Nagelkerke R-square \\
\hline $233.855^{\mathrm{a}}$ & .010 & .014 \\
\hline
\end{tabular}

Table G: Classification table for outcome-oriented culture

\begin{tabular}{lllll}
\hline Observed & \multicolumn{2}{l}{ Predicted } \\
\cline { 3 - 4 } & & MAPs & $\begin{array}{l}\text { Percentage } \\
\text { Correct }\end{array}$ \\
\cline { 3 - 4 } & $\mathbf{0}$ & $\mathbf{1}$ & \\
\hline MAPs & 0 & 16 & 59 & 21.3 \\
& 1 & 5 & 92 & 94.8 \\
Overall Percentage & & & & 62.8 \\
\hline
\end{tabular}


Table H: Variables in the equation for outcome orientation culture

\begin{tabular}{llllllll}
\hline & & B & S.E. & Wald & Df & Sig. & $\operatorname{Exp(B)}$ \\
\hline Step 1 & & & & & \\
& Outcome & .244 & .184 & 1.753 & 1 & .185 & 1.276 \\
& Constant & -.261 & .419 & .387 & 1 & .534 & .770 \\
\hline
\end{tabular}

Table I: Omnibus tests of model coefficients for people orientation culture

\begin{tabular}{lllll}
\hline & & Chi-square & Df & Sig. \\
\hline Step 1 & Step & .449 & 1 & .503 \\
& Block & .449 & 1 & .503 \\
& Model & .449 & 1 & .503 \\
\hline
\end{tabular}

Table J: Model summary for people orientation culture

\begin{tabular}{lll}
\hline $\mathbf{- 2}$ Log-likelihood & $\begin{array}{l}\text { Cox and Snell } \\
\text { R-square }\end{array}$ & Nagelkerke R-square \\
\hline $235.172^{\mathrm{a}}$ & .003 & .003 \\
\hline
\end{tabular}

Table K: Classification table for people orientation culture

\begin{tabular}{llllll}
\hline & Observed & \multicolumn{2}{l}{ Predicted } \\
\cline { 3 - 4 } & & \multicolumn{2}{l}{ MAPs } & Percentage \\
\cline { 5 - 5 } & & $\mathbf{0}$ & $\mathbf{1}$ & Correct \\
\hline Step 1 & MAPs & 0 & 3 & 72 & 4.0 \\
& & 1 & 0 & 97 & 100.0 \\
& Overall percentage & & & 58.1 \\
\hline
\end{tabular}

Table L: Variables in the equation for people orientation culture

\begin{tabular}{|c|c|c|c|c|c|c|c|}
\hline & & B & S.E. & Wald & Df & Sig. & $\operatorname{Exp}(B)$ \\
\hline \multirow[t]{2}{*}{ Step $1^{a}$} & People & .124 & .185 & .448 & 1 & .503 & 1.132 \\
\hline & Constant & -.034 & .460 & .005 & 1 & .942 & .967 \\
\hline
\end{tabular}

Table M: Omnibus tests of model coefficients for aggressive culture

\begin{tabular}{llll}
\hline & Chi-square & Df & Sig. \\
\hline Step & 4.223 & 1 & .040 \\
Block & 4.223 & 1 & .040 \\
Model & 4.223 & 1 & .040 \\
\hline
\end{tabular}

Table N: Model summary for aggressive culture

\begin{tabular}{lll}
\hline $\mathbf{- 2}$ Log-likelihood & Cox and Snell R-square & Nagelkerke R-square \\
\hline $231.398^{\mathrm{a}}$ & .024 & .033 \\
\hline
\end{tabular}

Table 0: Classification table for aggressive culture

\begin{tabular}{llllll}
\hline \multirow{2}{*}{ Observed } & \multicolumn{3}{l}{ Predicted } \\
\cline { 3 - 5 } & & \multicolumn{2}{l}{ MAPs } & \multirow{2}{l}{$\begin{array}{l}\text { Percentage } \\
\text { Correct }\end{array}$} \\
\cline { 3 - 4 } & & $\mathbf{0}$ & $\mathbf{1}$ & \\
\hline Step 1 & MAPs & 0 & 13 & 62 & 17.3 \\
& & 1 & 14 & 83 & 85.6 \\
& Overall percentage & & & & 55.8 \\
\hline
\end{tabular}

Table P: Variables in the equation for aggressive culture

\begin{tabular}{lrrrrrr}
\hline & B & S.E. & Wald & Df & Sig. & $\operatorname{Exp(B)}$ \\
\hline Aggressive & .384 & .189 & 4.119 & 1 & .042 & 1.468 \\
Constant & -.781 & .533 & 2.147 & 1 & .143 & .458 \\
\hline
\end{tabular}

Table Q: Omnibus tests of model coefficients stability culture

\begin{tabular}{lllll}
\hline & & Chi-square & Df & Sig. \\
\hline Step 1 & Step & 12.956 & 1 & .000 \\
& Block & 12.956 & 1 & .000 \\
& Model & 12.956 & 1 & .000 \\
\hline
\end{tabular}

Table R: Model summary for stability culture

\begin{tabular}{lll}
\hline $\mathbf{- 2}$ Log-likelihood & $\begin{array}{l}\text { Cox and Snell } \\
\text { R-square }\end{array}$ & Nagelkerke R-square \\
\hline $222.665^{\mathrm{a}}$ & .073 & .097 \\
\hline
\end{tabular}

Table S: Classification table for stability culture

\begin{tabular}{|c|c|c|c|c|c|}
\hline & \multirow[t]{3}{*}{ Observed } & & \multicolumn{3}{|c|}{ Predicted } \\
\hline & & & \multicolumn{2}{|c|}{ MAPs } & \multirow{2}{*}{$\begin{array}{l}\text { Percentage } \\
\text { Correct }\end{array}$} \\
\hline & & & 0 & 1 & \\
\hline \multirow[t]{3}{*}{ Step 1} & MAPS & 0 & 17 & 58 & 22.7 \\
\hline & & 1 & 12 & 85 & 87.6 \\
\hline & Overall percentage & & & & 59.3 \\
\hline
\end{tabular}

Table T: Variables in the equation for stability culture

\begin{tabular}{lrrrrrr}
\hline & B & S.E. & Wald & df & Sig. & $\operatorname{Exp(B)}$ \\
\hline Stability culture & .688 & .199 & 11.892 & 1 & .001 & 1.989 \\
Constant & -1.599 & .560 & 8.145 & 1 & .004 & .202 \\
\hline
\end{tabular}


Table U. Omnibus Tests of model coefficients for attention to details culture

\begin{tabular}{lllll}
\hline & & Chi-square & Df & Sig. \\
\hline Step 1 & Step & 23.833 & 1 & .000 \\
& Block & 23.833 & 1 & .000 \\
& Model & 23.833 & 1 & .000 \\
\hline
\end{tabular}

Table V. Model summary for attention to details culture

\begin{tabular}{llll}
\hline Step & $\begin{array}{l}\mathbf{- 2} \text { Log- } \\
\text { likelihood }\end{array}$ & $\begin{array}{l}\text { Cox and Snell } \\
\text { R-square }\end{array}$ & $\begin{array}{l}\text { Nagelkerke } \\
\text { R-square }\end{array}$ \\
\hline 1 & $211.788^{\mathrm{a}}$ & .129 & .173 \\
\hline
\end{tabular}

Table W. Classification table for attention to details culture

\begin{tabular}{|c|c|c|c|c|c|}
\hline & \multirow[t]{3}{*}{ Observed } & & \multicolumn{3}{|c|}{ Predicted } \\
\hline & & & \multicolumn{2}{|c|}{ MAP } & \multirow{2}{*}{$\begin{array}{l}\text { Percentage } \\
\text { Correct }\end{array}$} \\
\hline & & & 0 & 1 & \\
\hline \multirow[t]{3}{*}{ Step 1} & MAP & 0 & 55 & 20 & 73.3 \\
\hline & & 1 & 37 & 60 & 61.9 \\
\hline & Overall Percentage & & & & 66.9 \\
\hline
\end{tabular}

a The cut value is .500

Table X: Variables in the equation for attention to details culture

\begin{tabular}{|c|c|c|c|c|c|c|c|}
\hline & & B & S.E. & Wald & Df & Sig. & $\operatorname{Exp}(B)$ \\
\hline \multirow[t]{2}{*}{ Step $1^{a}$} & Attention & -1.091 & .244 & 19.926 & 1 & .000 & .336 \\
\hline & Constant & 3.290 & .716 & 21.105 & 1 & .000 & 26.831 \\
\hline
\end{tabular}

Table Y: Omnibus tests of model coefficients for a teamwork culture

\begin{tabular}{lllll}
\hline & & Chi-square & Df & Sig. \\
\hline Step 1 & Step & 13.222 & 1 & .000 \\
& Block & 13.222 & 1 & .000 \\
& Model & 13.222 & 1 & .000 \\
\hline
\end{tabular}

Table Z. Model summary for a teamwork culture

\begin{tabular}{llll}
\hline Step & $\begin{array}{l}\mathbf{- 2} \text { Log- } \\
\text { likelihood }\end{array}$ & $\begin{array}{l}\text { Cox and Snell } \\
\text { R-square }\end{array}$ & $\begin{array}{l}\text { Nagelkerke } \\
\text { R-square }\end{array}$ \\
\hline 1 & $222.399^{\mathrm{a}}$ & .074 & .099 \\
\hline
\end{tabular}

Table A1: Classification table for teamwork culture

\begin{tabular}{|c|c|c|c|c|c|}
\hline & \multirow[t]{3}{*}{ Observed } & & \multicolumn{3}{|c|}{ Predicted } \\
\hline & & & \multicolumn{2}{|c|}{ MAP } & \multirow{2}{*}{$\begin{array}{l}\text { Percentage } \\
\text { Correct }\end{array}$} \\
\hline & & & 0 & 1 & \\
\hline \multirow[t]{3}{*}{ Step 1} & \multirow[t]{2}{*}{ MAP } & 0 & 53 & 22 & 70.7 \\
\hline & & 1 & 42 & 55 & 56.7 \\
\hline & \multicolumn{4}{|c|}{ Overall percentage } & 62.8 \\
\hline
\end{tabular}

a The cut value is .500

Table A2: Variables in the equation for a teamwork culture

\begin{tabular}{llllllll}
\hline & & $B$ & S.E. & Wald & Df & Sig. & $\operatorname{Exp(B)}$ \\
\hline Step 1 & & & & & & \\
& Teamwork & -.769 & .224 & 11.729 & 1 & .001 & .464 \\
& Constant & 1.998 & .544 & 13.467 & 1 & .000 & 7.371 \\
\hline
\end{tabular}

${ }^{a}$ Variable(s) entered on step 1: Teamwork

\section{Appendix 3: Factor Analysis and Reliability Tables}

Factor Analysis for the modern management accounting practices

\begin{tabular}{ll}
\hline & Components \\
\hline Target costing & .684 \\
Activity-based management & .674 \\
Throughput accounting & .660 \\
Quality costing & .656 \\
Backflush costing & .622 \\
Activity-based budgeting & .611 \\
Life cycle costing & .608 \\
Value chain analysis & .541 \\
Just in time & .509 \\
Balanced Score Card & .502 \\
Kaizen Costing & .397 \\
Activity-Based Costing & .389 \\
Product Profitability analysis & .339 \\
Benchmarking & .239 \\
Shareholder value analysis/Economic Value Analysis & -.116 \\
Extraction Method: principal component analysis. & \\
\hline & \\
Reliability Tests for the Modern Management & Accounting \\
Practices & \\
\hline Reliability statistics & \\
\hline Cronbach's alpha & 12 \\
\hline 787 &
\end{tabular}




\section{Reliability Tests for Firm Culture}

Reliability statistics

Cronbach's alpha

$\mathrm{N}$ of Items

.780

7

Received: 24 August 2019 Accepted: 13 August 2020

Published: 10 September 2020

\section{References}

1. Ajibolade SO (2013) Drivers of choice of management accounting system designs in Nigerian manufacturing companies. Int J Bus Soc Res (IJBSR) 3:45-57

2. Albu N, Albu C (2011) Factors associated with the adoption and use of management accounting techniques in developing countries : the case of Romania. J Int Financ Manag Account 2011:245-267. https://doi. org/10.1111/jifm.12002

3. Ax C, Greve J (2017) Adoption of management accounting innovations: organizational culture compatibility and perceived outcomes. Manag Account Res 34:59-74. https://doi.org/10.1016/j.mar.2016.07.007

4. Ayeni RK (2012) An Firms assessment of profit function of manufacturing in Nigeria during global economic depression : a panel model approach. Ozean J Soc Sci 5(2):41-48

5. Baines A, Langfield-Smith K (2003) Antecedents to management accounting change: a structural equation approach. Acc Organ Soc 28(7-8):675-698. https://doi.org/10.1016/S0361-3682(02)00102-2

6. Baird K, Harrison G, Reeve R (2007) Success of Activity management practices: the influence of organizational and cultural factors. Account Financ 47(1):47-67

7. Baird KM, Harrison GL, Reeve RC (2004) Adoption of activity management practices: a note on the extent of adoption and the influence of organizational and cultural factors. Management Accounting Research 15(4):383-399. https://doi.org/10.1016/j.mar.2004.07.002

8. Bhimani A (2003) Management accounting in the digital economy. Oxford University Press, Oxford

9. Bhimani A, Bromwich M (2010) Management accounting: prospect and retrospect. Elsevier B.V, Great Britan

10. Bhimani A, Bromwich M (2010) Management accounting : retrospect and prospect, 1st edn. Elsevier, US

11. Brandt-Siemers JB (2019) Activity-based costing in higher education: a case study of three implementations. Capella University, Capella

12. Budi I, Nusa S (2015) Influence of organizational culture and structure on the quality of accounting information system. Int J Sci Technol Res 4(05):257-267

13. Burns J, Scapens RW (2000) Conceptualizing management accounting change: an institutional framework. Manag Account Res 11(1):3-25

14. Charaf K, Bescos P (2013) The role of organizational and cultural factors in the adoption of activity-based costing: the case of Moroccan firms. Account Manag Inf Syst 12(1):4-21

15. Chenhall RH, Kallunki J-P, Silvola H (2011) Exploring the relationship between strategy, innovation and management control systems: the role of social networking, organic innovative culture and formal controls. J Manag Account Res 23(1):99-128

16. Chenhall RH, Langfield-Smith K (1998) The relationship between strategic priorities, management techniques and management accounting: an empirical investigation using a systems approach. Acc Organ Soc 23(3):243-264

17. Chongruksut W (2009) Organizational culture and the use of management accounting innovations in Thailand. RU Int J 3(1):113-126

18. Deem JW, Barnes B, Segal S, Preziosi R (2010) The relationship of organizational culture to balanced scorecard effectiveness. SAM Advanced Management Journal 75(4):1

19. Donaldson L (2001) The contingency theory of organizations. Sage Publication Ltd, London

20. Donaldson $L$ (2005) For positive management theories while retaining science: reply to Ghoshal. Acad Manag Learn Educ 4(1):109-113
21. Duh R, Xiao JZ, Chow CW (2009) Chinese firms' use of management accounting and controls: facilitators, impediments, and performance effects. J Int Account Res 8(1):1-30. https://doi.org/10.2308/jiar.2009.8.1.1

22. Emmanuel C, Otley D, Merchant K (1990) Accounting for management control, 2nd edn. Chapman \& Hall, London

23. Field A (2009) Discovering statistics using SPSS, 3rd edn. Sage Publication Ltd., London

24. Frigo ML, Williams K (2019) Management Accounting. Strateg Financ $1: 38-43$

25. Ghasemi R, Mohamad NA, Karami M, Bajuri NH (2015) The relationship among strategy, competition and management accounting systems on organizational performance. Eur J Nat Soc Sci 4(3):565-581

26. Gong MZ, Tse MSC (2009) Pick, mix or match? A discussion of theories for management accounting research. Journal of Accounting Business and Management 16:54-66

27. Haldma T, Lääts K (2002) Influencing contingencies on management accounting practices in Estonian manufacturing companies

28. Hopper T, Tsamenyi M, Uddin S, Wickramasinghe D (2009) Management accounting in less developed countries: what is known and needs knowing. Account Audit Accountabil J 22(3):469-514. https://doi. org/10.1108/09513570910945697

29. Hussain MM, Hoque Z (2002) Understanding non-financial performance measurement practices in Japanese banks: New institutional sociology perspectives. Account Audit Accountabil J 15(2):162-183

30. Jhonson HT, Kaplan RS (1987) Relevance lost: The rise and fall of management accounting. Harvard Business School Press, Boston

31. Junqueira E, Dutra EV, Zanquestto FH, Gonzaga RP (2016) The effect of strategic choices and management control systems on organizational performance. R Cont Fin-USP Sao Paulo 7:1-15. https://doi. org/10.1590/1808-057×201601890

32. Kapiyangoda K (2018) Institutions, agency, culture and control : a case study of a multinational operating company. J Account Organ Change 14(4):402-428. https://doi.org/10.1108/JAOC-07-2017-0056

33. Kevin B, Kristal JH, Robert R (2011) The relationships between organizational culture, total quality management practices and operational performance. Int J Oper Prod Manag 37(1):789-814

34. Kothari C, Garg G (2019) Research methodology: methods and techniques (Fourth). www.newagepublisher.com

35. Kothari CR, Garg G (2014) Research methodology : methods and techniques, 3rd ed. New Age International

36. Mat TZT, Smith M (2014) The impact of changes in environment and AMT on management accounting practices and organizational strategy, structure and performance. J Appl Manag Account Res 12(1):55-82

37. Mat TZT (2010) Management accounting and organizational change: Impact of alignment of management accounting systems, structure and strategy on performance. Edith Cowan University, Perth Western Australia

38. McKinley W, Mone MA (2003) Micro and macro perspectives in organization theory: a tale of incommensurability. In: The Oxford handbook of organization theory, pp 345-372

39. Nagirikandalage $P$, Binsardi B (2017) Inquiry into the cultural impact on cost accounting systems (CAS) in Sri Lanka. Manag Audit J 32(4-5):463499. https://doi.org/10.1108/MAJ-02-2016-1313

40. Napitupulu IH (2018) Organisational culture in management accounting information system: survey on State-owned Enterprises(SOEs) Indonesia. Glob Bus Rev 19(3):556-571

41. Naranjo-Valencia JC, Jimenez-Jimenez D, Valle RS (2011) Innovation or imitation? The role of organizational culture. Manag Decis 49(1):55-72

42. Nor-Aziah AK, Scapens RW (2007) Corporatisation and accounting change: the role of accounting and accountants in a Malaysian public utility. Manag Account Res 18(2):209-247

43. Nuatip S (2016) Management accounting changes and the interaction effect of management accounting practices and integrated information systems on organizational performance: evidence from Thailand. https:// search.proquest.com/docview/1913432741?accountid=198529

44. O'Reilly C, Chatman J, Caldwell D (1991) People and organizational culture: a profile comparison approach to assessing person-organization fit. Acad Manag J 34(3):487-516

45. Ojua MO (2016) Strategic management accounting practices among indigenous Nigerian manufacturing enterprises. Open Sci J 1(2):1-14. https://doi.org/10.23954/osj.v1i2.395 
46. Ominunu OG (2015) Management information and accounting system and organizational performance in Nigeria. Am J Soc Manag Sci 6(1):1-17. https://doi.org/10.5251/ajsms.2015.6.1.17

47. Organizational Behavior (2017) University of Minnesota Libraries Publishing

48. Oyerogba EO (2015) Management accounting practices in the developing economies: the case of Nigeria listed companies. J Account Manag 5(2):76-85

49. Pasch $T$ (2019) Strategy and innovation: the mediating role of management accountants and management accounting systems' use. J Manag Control 30(2):213-246. https://doi.org/10.1007/s00187-019-00283-y

50. Pituch KA, Stevens JP (2016) Applied multivariate statistics for the social sciences: analyses with SAS and IBM's SPSS, 6th edn. New York Routledge, New York

51. Rababah A (2015) The relationship between cultural factors and balanced scorecard implementation. Int Rev Manag Bus Res 4(4):1208-1218

52. Ribeiro JA, Scapens RW (2006) Institutional theories in management accounting change. Qual Res Account Manag 3(2):94-111. https://doi. org/10.1108/11766090610670640

53. Robalo R (2014) Explanations for the gap between management accounting rules and routines: an institutional approach. Span Account Rev 17(1):88-97

54. Simionescu S, Bică E (2016) Influence factors social and cultural rights on the evolution of management accounting. J Adv Res Manag 7(2):96-101. https://doi.org/10.14505/jarm.v7.2(14).03
55. Thompson J (2005) The time we waste. Manag Today 1:44-47

56. Thompson S (2006) Kraft CEO slams company, trims marketing staff. Advertising Age 1:3-62

57. Van der Stede WA, Young SM Chen CX (2007) Doing management accounting survey research. Handbook of Management Accounting Research

58. Velasquez S, Suomala P, Järvenpää M (2015) Cost consciousness: conceptual development from a management accounting perspective. Qual Res Account Manag 12:55-86. https://doi.org/10.1108/ORAM-07-2013-0029

59. Waweru NM, Hoque Z, Uliana E (2004) Management accounting change in South Africa. Account Audit Account J 17(5):675

60. Westrum R (2004) Increasing the number of guards at nuclear power plants. Risk Analysis: An International Journal 24:959-961

61. Yigitbasioglu OM (2017) Drivers of management accounting adaptability: the agility lens. J Account Organ Change 13(2):262-281. https://doi. org/10.1108/JAOC-12-2015-0092

\section{Publisher's Note}

Springer Nature remains neutral with regard to jurisdictional claims in published maps and institutional affiliations.

\section{Submit your manuscript to a SpringerOpen ${ }^{\circ}$ journal and benefit from:}

- Convenient online submission

- Rigorous peer review

- Open access: articles freely available online

- High visibility within the field

- Retaining the copyright to your article

Submit your next manuscript at $\boldsymbol{\nabla}$ springeropen.com 